\title{
THE IMPLEMENTATION OF CHARACTERISTICS OF ORGANIZATIONAL CULTURE "SHARING" BASED ON LOCAL WISDOM IN INCREASING HR COMPETENCE IN INDONESIA (FACING ASIAN FUTURE SHOCK 2020)
}

\author{
Mulyaningsih \\ mulyaningsih@gmail.com
}

\begin{abstract}
Indonesia as the country with the opportunity cost of investment and the highest corruption in ASIA business caused a cultural and population changes which is affect to family structure in the development business and state. Based on those conditions, Indonesia must change fast become count country in ASIA to build character through local knowledge possessed a vast country and large The shift in the pattern of the surviving members of regional communities is an indicator of impending shocks to the mindset, ways of thinking, feeling and reacting based on the environment and the condition of the demands of the behavior of the members together are embraced and accepted by the organization to act and solve problems, adapt and unites members of the organization through a shift in values, norms and cultural rules significantly (mean) the impact of the shock towards the life of the nation both by employers and stakeholders organizations in Indonesia. ASIA development of the business sector in the 21 st century emphasizes ethical investment. Ethical investments In the 21st century, supporting ethical organization, including in developed countries the problem of ethics and organizational behavior into consideration when deciding policies and financial. The idea of ethical investment had various depend on each country, and company cultural perception. The application of ethical investment strategies of individual, non-profit organizations, governments and companies to attract potential investors, in the hope that the fund is managed in a way that does not have a negative impact on society, including Indonesian society. The influence of cultural, social and geographical had very strong impact to employers and stakeholders behavior. The diversity behavior is fundamental basic considered in fundamentals treatment will support the success of Indonesia development over this years. It will deal with the honesty, integrity in the right employees, strong leadership and support for ethnic behavior. Those conditions would cause a shock to the human resources therefore need nation quality recovery in national policies circle in order to determine direction of attitudes change and nation view as an interactive consequence in organizational culture characteristic which is owned Indonesian HR should be able to function as a tool to support the implementation of the development progress through employee competence and leadership. The Indonesian efforts to increase capacity and competence of the Human Resources (HR) with respect to resilience in the face of 2020, namely the implementation of a characteristic of organization culture that will affect the way work is done and how employees behave based on the philosophy of Pancasila and the results of research in the form of build character first through local wisdom in the sunda level; like "sareundeuk saigel sabobot sapihanean, penance grindstones penance foster compassion, silih simbeuh mean to share (Sharing). (Mulyaningsih, Japan Meijo 2015) The paradigm of thought in enhancing the competence of behaving for Human Resources in Indonesia by sharing (sharing) the future is not only to be able to survive in the economic crisis but as a cornerstone in carrying out the work or the owner (owner) as well as the investors who use ethical investment as competence businesses, professional stakeholders to support the business sector and the advantages of statehood in Indonesia capable of competitiveness in 2020.
\end{abstract}

Keywords: sharing 


\section{INTRODUCTION}

Based on the idea of Beckham 2008 in Asian Future shock, that the influence of cultural change and population on Asian business affecting Indonesia as a country that has a cost of investment and opportunities for highest corruption in business so it is less meaningful position Indonesian Country in the business sector of Asian countries because investment costs are very expensive.

Human Resource (HR) in Indonesian Country as the third most populous country in the world influences the change of family structure in business development. Based on the conditions above Indonesia must change in pursuing to become State calculated in Asian by building character through local knowledge possessed as a wide and big country so also that:

The issue of urbanization, conditions, economic, financial and even culture in some Asian countries like, India, Vietnam, China, Malaysia and even Indonesia will lead to a shift in the pattern of the surviving members of regional communities are indicators will occur a shock across paradigms, ways of thinking, feeling and reacting based on the environment and the condition to the behavioral demands of the members together embraced and accepted by the organization to act and solve problems, to adapt and to unite members of the organization through a shift in values, norms and cultural rules significantly (mean) impacting towards shock in the national life. (Mulyaningsih, Japan Meijo University in 2015).

Asian business sector in the 21st century will be more of the sectors that require Ethical Investment.

"Ethical Investments in the 21st century, ever more people who support ethical organizations with their money. In the United States alone, it is estimated that three-quarters of investors to take the problem of ethics and organizational behavior into consideration when deciding where to commit their funds. The idea of ethical investment varies according to country and depends on the perception of their company culture and practices. Strategic ethical investment being embraced by individuals, nonprofit organizations, governments and companies to attract potential investors, in the hope that the fund is managed in a way having no negative impact on society. (Linda \& O.C.Farrel 2009).

For Indonesian Country ethical investment has been running for a long time, such investments managed by a Small-Medium Enterprises, mostly aimed not generate profit or gain as much as possible but to the needs and welfare of its members or family than as a tool to maintain national welfare and revive the country's economy such as the role of SME in Indonesia have been shown to survive in times of crisis than as support for Indonesian country's economy during this time.

The importance of small and medium enterprises in the industrial development in developing countries has been demonstrated with toughness. In the Indonesian context, the development of small and medium enterprises have a strategic significance, namely to expand job and business opportunities and to increase the degree of income distribution so as to raise the Indonesian economy from the economic crisis to the economic recovery towards the better.

Mulyaningsih (2002) small and medium enterprises in Indonesia hailed by most people to contribute approximately $99 \%$ in the number of business entities. Even more remarkable absorb the portion of $98 \%-99.6 \%$ of the workforce in Indonesia. Deputy Coordinating Minister of Economy of Industry, Trade and Small Business Empowerment medium/SME, 
Dipo Alam. (Kompas, 14 Des 2001), therefore if the business sector is strong it will be a good contribution in the economic recovery in Indonesia.

The influence of cultural, social and geographical diversity is very strong against the behavior of small businesses. The diversity of behavior is fundamental to be considered in the treatment of this sector. And SMEs is a fundamental sector that will support the success of development in Indonesia during this time, as seen in the following table:

\section{Comparison}

Table 1.1 Position of SME Business Unit of 1994.1998, 2000, and Table 1.2 the number of Small and Medium Business and Large Business of 1997-2001

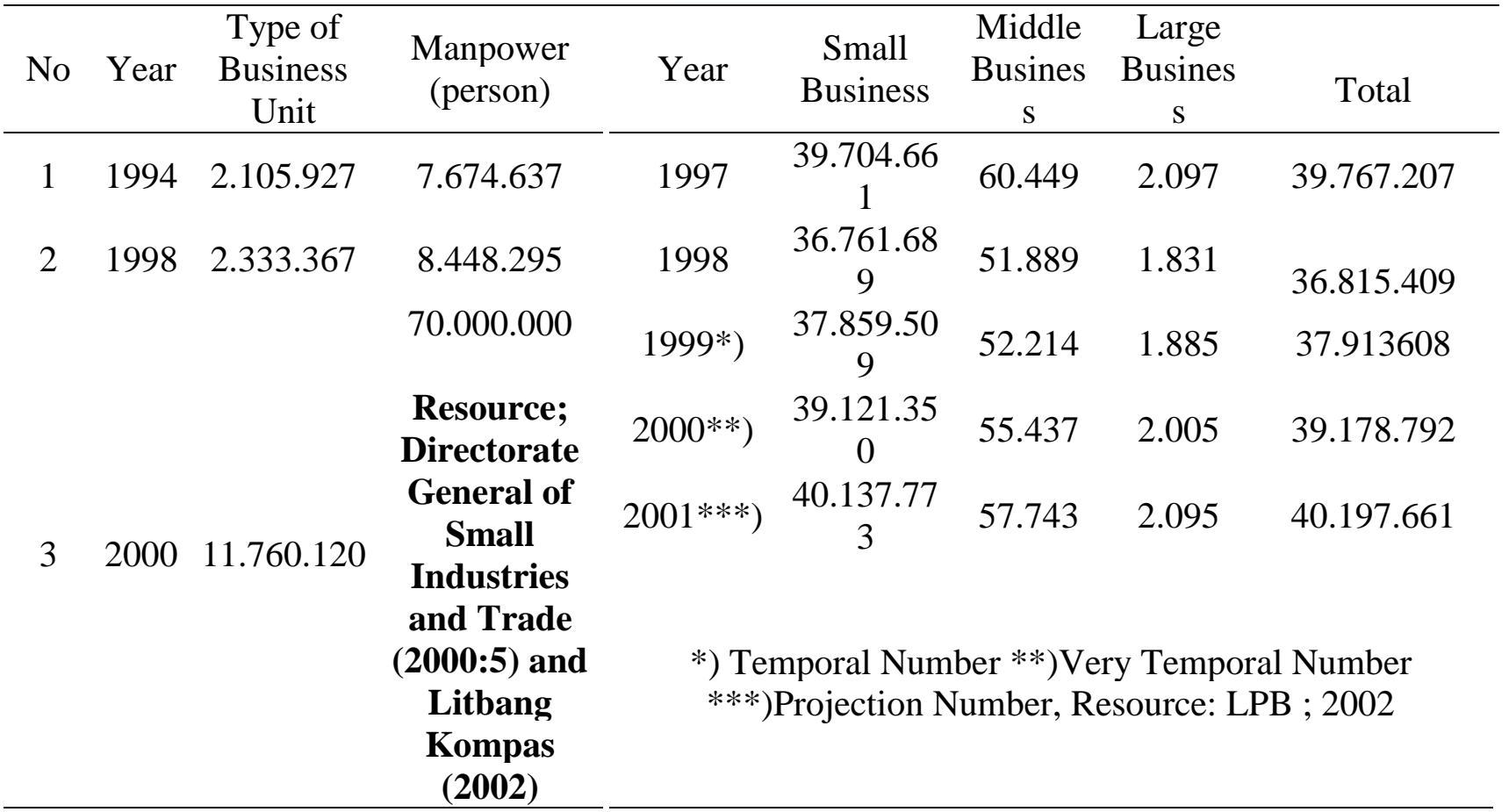

Source: Mulyaningsih; 2002

Table 1.3

Number of SME Development of 2012-2015

\begin{tabular}{cccccc}
\hline No & Year & $\begin{array}{c}\text { Number of } \\
\text { SME }\end{array}$ & $\begin{array}{c}\text { Number of } \\
\text { Player }\end{array}$ & $\begin{array}{c}\text { Absorption of } \\
\text { Manpower }\end{array}$ & $\begin{array}{c}\text { Credit of } \\
\text { Business } \\
\text { Classification }\end{array}$ \\
\hline 1 & $\mathbf{2 0 1 2}$ & $\mathbf{5 6 . 5 3 4 . 5 9 2}$ & $\mathbf{1 0 7 . 6 5 7 . 5 0 9}$ & $\mathbf{4 2 9 . 6 7 8}$ & $\mathbf{5 5 2 , 2 2 6 , 1}$ \\
$\mathbf{2}$ & $\mathbf{2 0 1 3}$ & $\mathbf{5 7 . 8 9 5 . 7 2 1}$ & $\mathbf{1 1 4 . 1 4 4 . 0 8 2}$ & $\mathbf{4 7 3 . 6 0 3}$ & $\mathbf{6 3 9 , 4 7 1 , 5}$ \\
$\mathbf{3}$ & $\mathbf{2 0 1 5}$ & $\mathbf{5 8 . 0 0 0 . 0 0 0 0}$ & $\mathbf{2 0 3 . 7 0 1 . 0 0 0}$ & $\mathbf{5 6 7 . 4 2 0}(\mathbf{9 8 \%})$ & $\mathbf{7 5 4 , 2 4 4 , 6}$ \\
\hline
\end{tabular}

Source: Bani Saksono (Syarifuddin Hasan, 2015),

Dhaniswara K Harjono (Data Source Bank/SME Development, Department-DPUM) 2015

Small and medium enterprises is the people's economic activities involving communities until to rural areas throughout Indonesia. Finally look so beautiful in the ruins of large enterprises. Various different background that there are a small business and act; of local and national economic realm, the realm of the family and household, the political sphere, to complicate efforts to understand the realm of small businesses in the context of the social and empowerment. (Mulyanto, AKATIGA; 2006) 
Motivation small and medium entrepreneurs to maintain the viability of the business tend to be very high because it is the only source of family income. This is in line with the characteristics of small businesses that have a relatively high business flexibility so that small businesses a relatively adaptive in the face of changing circumstances in the business environment. The company's goal will be achieved when companies can adjust to the environment/conditions circumstances.

The business decision involves a complex economic, legal and social in running the action and strategy of the organization. Consideration and many years of experience in the industry to understand the risks and expected behavior.

Good business has a strong ethics program running alongside other quality management systems in the form of a set of fundamental principles that guide the behavior of powerful and owned processes to ensure that these principles are applied. The key to success is strong leadership from employees enlightened who have been trained to understand the risks associated with their work and how to deal with "gray areas" (problem). (Linda \& OC Farrel, 2009). Ethics covers diverse business activities of maintaining work-life balance to assess the impact of globalization. In today's business environment, ethics will steer the organization away from the crisis and improve its financial success. (Linda \& 0, C.Farrel, 2009).

It will deal with the honesty in advertising, the integrity of the sales force and products that function effectively. Mistakes can and will happen within an organization without proper identification risks, proper training, strong leadership and support for ethnic behavior.

Future business formed due to the effect from occurring due to population and urbanization in Asia on a large scale so that the regional community experienced a shift in the pattern of life where the condition of Indonesia have low wages, corruption and high investment costs would potentially cause financial shock and culture (Beckham, 2008) it is necessary archetype accepted by the organization to act and solve the problem of mutual perception embraced by the Indonesian or the environment in Asian Future shock 2020. the above conditions would cause a shock to the human resources it needs improvement in the quality of the nation circle of national policy to set a direction change the attitudes of the nation as interactive consequences in the form of an organizational culture that possessed the characteristics of Indonesian human resources to be able to function as a tool to support the implementation progress of development through small and medium enterprises (SMEs) that have been proven toughness.

\section{Educational Implementation of Characteristics of Organizational Culture "Sharing"}

As for Indonesian efforts with respect to increasing the capacity and competence of human resources (HR) with respect to resilience in the face in 2020 is to build a characteristic value of organizational culture that will affect the way work is done and how employees behave based on the philosophy of Pancasila and research results in the form of building characters advance through local wisdom in the sunda level; like "sareundeuk saigel sabobot sapihanean, silih asah silih asih, silih simbeuh" intended as Sharing. (Mulyaningsih, Japan Meijo 2015).

Characteristics of organizational culture "sharing" is a characteristic that can be implemented into the behavior of perpetrators of human resources in SME economics, the political sector, the legal sector, social and cultural rights through character education in how to work the employees and grounding behave stakeholders, given the organizational culture is According 
to Robbins (2001: 510) states that "organizational culture Refers to a system of shared meaning held by members that distinguishes the organization from other organization." the definition can be explained that the organizational culture as a value, beliefs, practices that create a common understanding among the members of the organization. Armstrong (1995: 19) argues that organizational culture is a "pattern of attitudes, beliefs, assumptions and expectations shared, which may not be recorded, but shaping the way people act and interact in the organization and supporting how things get done"

For the people of Indonesia the conditions has also an impact on the state of shock of the values, norms and ways of thinking and behaving. It is very difficult to change quickly given the infrastructure in the form of political, economic, social and lifestyle the way human resources are still in the category have not been as good or as advanced as other countries in Asian region. However, Indonesia has many philosophical and values that sublime is not just a legacy but also has roots in society such as the values contained in Pancasila as a form of noble values of positive character who owned the nation Indonesia since long ago in the days empire (Nusantara) which examined from several studies including for Sunda level, "sareundeuk saigel sabobot sapihanean, silih asah silih asih, silih simbeuh" for urban communities (complex) with rural communities as a result of urbanization and urban city development, sharing and identity. Involvement; actively participate; consistency is to run mission-, simultaneity of work, the level of creativity. (Mulyaningsih-2010)

For the people of Indonesia in dealing with the impact of the values shift today and in the future have the characteristics of an organizational culture that boils down to philosophy of a country that has had the character of the Indonesian nation must be equipped with the cultural characteristics " Sharing "(sharing) than as a counterweight is also a tool and foundation for when Indonesia will face "Indonesian Culture Future Shock" given the characteristics of the "Sharing" (Sharing) is the incarnation of the noble values of the nation Indonesia in Pancasila which has existed since long been implemented in the life of the nation Indonesia as Silih Simbeuh at the level of West Java, it already exists in people's lives even the Sundanese of West Java in general. application development (Reconstruction) values in the characteristics of the organizational culture "Sharing" (sharing) to increase the competence of the competitiveness of human resources (HR) included in businesses such as SMEs, stakeholders in Indonesia should be thinking along toward changing the attitudes of the nation as a consequence of human interactive as the individual in relation to community, national, regional and international levels. Porter in his book "The competitive Advantage of nations", said that the theory of a country's competitiveness is correlation rests on development of human resources. (Meijo, 2015).

Philosophical foundation will affect the way work is done and how employees behave based on the philosophy of Pancasila and the results of the research is to build character in advance through local wisdom and Pancasila. The foundation for the development of small businesses that specifically refers to the precepts 5th namely: social justice for all the people of Indonesia are "Populist" in the sense of prosperity for communities to come first, not the prosperity of individual persons. Small businesses, the fair treatment of all economic actors. (Hetifah Sjaifudian, Dede Haryadi and Maspiyanti, 20: 1995).

As for paradigm of thought in enhancing the competence of behavior for human resources (HR) in Indonesia in the future not only to survive in the economic crisis but as a cornerstone in carrying out the work or the owner (owner) as well as the investors who use ethical investment as human resources deploying SMEs, professional stakeholders to support the 
business sector and the advantages of statehood in Indonesia competitiveness in 2020. the paradigm of thinking characteristic of organizational culture in the act of human resources (HR) in Indonesia to the front through the characteristics of sharing (Sharing) awakens from the framework as follows:

\section{Paradigm \\ Characteristics of Organizational Culture "Sharing" Behavior of human resources in} Indonesia

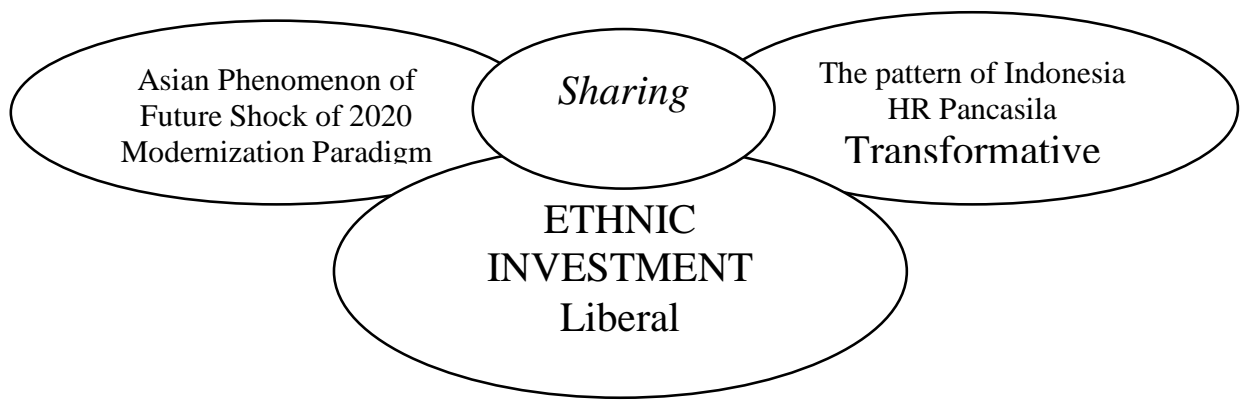

The framework as a paradigm of organizational culture characteristic "Sharing" behavior of human resources in Indonesia will be the implementation of behavioral competencies of HR in improving the nation's competitive advantage through a philosophical stance in terms of Silih Simbeuh; Desperate for money, with the ability to establish a relationship with a "safety net" and other businesses that are willing "rivaled" The pattern of social relations and production which are built into informal relationships provides a guarantee socio-economic for the workers, the use of cultural trademarks of China (utilizing the combined purchase for save costs, take advantage of cooperative trustworthy, combining many small orders; saving labor and time; look for detailed information on market conditions; and combinations of supplier) relationships entrepreneurs with capital sources and suppliers of raw materials are often personalized in a reciprocal relationship Advantageously, Silih Asah Silih Asih Silih Asuh in the terms of anti-monopoly stance, creating a labor-employer relations format informal, gender against large-scale production in male involvement "in the levels of stakeholders, structural-policy, Indonesia decisive advantage competitiveness the results of the industry in the global market is the large number of workers from the class of poorly educated and abundant raw materials, Global trade, Risk exploitation faced by small industries will be even greater when the trading chain streaming down in international market through a manner used to indicate a partnership between two or more business units in production activities. The relation between the subcontractors with workers is labor-employer (dunungan). Relationship-chartering agreement to create a job-specific work for the other. The relation between the subcontractors with workers is labor-employer (dunungan). (Malaysia; Mulyaningsih; 2015).

Characteristics of the identity of the above explains that every employee behavior can be determined by personal characteristics form the basis of how these employees can work better. And other specific characteristics possessed very supportive employee job performance of the employee concerned. Employee behavior observed by the leadership may be a behavioral observation tools employees work in accordance with the provisions stipulated. (Mulyaningsih, 2014).

Thus the vision of the government of Indonesia is assumed to reach its goal precisely not in 2020 but can be achieved by 2018 and will enter six (6) countries with the largest economies in the world by purchasing power parity, the USA, Japan, China, India, Germany and Indonesia. The optimistic picture is a morale booster for the people of Indonesia as released 
Global Competitiveness Report, that Indonesia ranks 15 countries included in the most competitive and rank 4 (four) the most attractive country for investment and bring Indonesia as The Emerging Tiger and The New Beggar.

Readiness to build local human resources to build the character of the characteristics of organizational culture "shared" through local knowledge possessed as a large country and a large part an effort to build trust Indonesian society by empowering and making it a point characteristic of Indonesian human resources that is needed is the ability (ability) measured the characteristics of the "sharing" (sharing) as a means of unifying the population Indonesia business, national and state or have that makes HR Indonesia as "a model of sharing" and a change agent (the agent of changes) and never stop identity as a great nation, sovereign and has philosophical formidable.

Context builds strategic human resources must contribute to the achievement of competitive advantage because it is based on the situational conditions of basic needs or counteract the demands facing Asian Future Shock by performing reconstruction of education policies that are relevant to the needs of building an organizational culture characteristic "share" of the Indonesian nation.

The good performance is not only determined by the strong internal business network among entrepreneurs in these centers, but also influenced by the external network. Social environmental factors-culture conducive is also one of the preconditions for the establishment of a center for successful because these aspects affect social relationships among fellow entrepreneurs and businessmen with merchants which was facilitated by the government as the policy holder in terms of the application (implementation of the re-education of local wisdom owned in the joint national education.

The identity of the bureaucratic apparatus of government consists of indicators of personal characteristics, special features, and observe the behaviors affect the organization the effectiveness of the government represented by the factor of adaptability, productivity, job satisfaction, profitable capability and sourcing. Characteristics of identity is the extent to which the level of the member identifies himself with the organization as a whole rather than with a particular work group or field of professional expertise.

Characteristics of the identity of the above explains that every government employee behavior can be determined by personal characteristics form the basis of how these employees can work better. And other specific characteristics possessed very supportive employee job performance of the employee, the employee behavior is observed by the leadership may be a behavioral observation tools employees work in accordance with the provisions stipulated in accordance with Kreitner and Kinichi (2003: 78) states that:

1. "Culture determines an organization's overall personality and has a strong influence on the behavior of its members.

2. Culture can be observed for ceremonies, rituals, stories, heroes and symbols of the company.

3. This culture containing the spread of the values of the underlying companies.

4. With a strong culture, its members behave with the understanding that supports the achievement of the important objectives of the company.

5. The leadership of the organization making the spread of values and the use of stories, ceremonies, heroes and good language to reinforce these values in day-to-day life". 
Indicators private from each apparatus, educators and policy makers education and other specific characteristics possessed by the authorities as well as the individual's ability to observe the behavior as part of the values, symbols and understanding of the behavior of officials in everyday life as a member of the government officials to support the achievement of government objectives is an indicator that affects the flexibility to adapt, productivity, job satisfaction, profitable capability and sourcing.

Responsibility for the job is a definite provisions, and employees have the freedom to act, but can be accounted for, so the willingness of work created by the impulse itself is not on the basis of compulsion as characteristic of individuals based Islamic. In terms of the success of effectiveness is through adaptability involves mental and emotional employees, the maturity of employees affect the adaptation of employees and get each part accelerate socialization work environment, the participation of employees in decision making advance the objectives/productivity, achievement of the work according to the procedure of work/job satisfaction, deal complex organizational structures to support employees in work/gainful ability, quantitative support facilities do not determine the effectiveness of organizational objectives/ability to use resources.

\section{Closing}

Organizational culture "sharing" and bureaucracy behavior, educators and policy makers of education as an agent of change in the running process of learning and teaching to the community so that the journey will affect the effectiveness of the organization of the nation's education culture larger organizations contributed compared with the behavior of the bureaucracy, meaning the organizational culture priority attention of education officials as competent human resources to the effectiveness of educational organizations throughout the agency can be achieved. Behavior educational policy makers, educators, community leaders, owner/entrepreneurs are generally characterized and motivated by the culture of the organization "sharing" of officials who adopt and transform the conditions that come from the environment to the public as the ancestral form of ethical values kabaheulaan sauyunan, sareundeuk saigel, sabobot sapihanean, uniform use solontong (clothing pangsi black and nyoren bag bubuy) and Islamic yourself bureaucrats with their day or time of worship (sunset Koran), dressing area (kabaya and solontong/pangsi) on certain days, pilgrimage Friday, and speaking area in a given day is uniformly applied starting from education, educational institutions and the general public will be able to improve the nation's progress through the adopters and regenerating local property previously existed and to make fundamental for the nation of Indonesia to rebuild competence and sense of patriots, heroic in reaching development through the implementation of educational characteristics "sharing/share" a lever of competitiveness of nations in 2020.

\section{REFERENCES}

Ferrell, Linda \& O.C. Ferrel, Ethical Business, Essential Managers, Dk, London, New York, Munich, Melbourne, Dehli, 2009.

Mulyaningsih, Proceeding; Joint Seminar KORPRI Region IV, Tsukuba University And Meijo University, Japan, 2015.

Mulyanto, Dede, Small Businesses And The Problems in Indonesia, AKATIGA, Bandung, 2006

Nelson Oly Ndubisi, Small And Medium Enterprises: In The Pacific Rim, KHL Printing Co.Sdn.Bhd. Malaysia 2008. 